UDC 930.2(477):94:352.07(477)"1941/1944"

DOI 10.24919/2519-058X.21.246911

\title{
Oleksij HONCHARENKO
}

PhD hab. (History), Professor of the Department of Theory and Methods of Technological Education and Computer Graphics, Hryhorii Skovoroda University in Pereiaslav, 30 Sukhomlynsky Street, Pereiaslav, Kyiv region, Ukraine, postal code 08401 (oleksijghoncharenko@gmail.com)

ORCID: 0000-0002-8882-6397

ResearcherID: AAC-1919-2020

\section{Oleksandr POTYL'CHAK}

PhD hab. (History), Professor, Head of Department of Original and Special Historical Sciences of the National Pedagogical Drahomanov University, 6 Osvity Street, Kyiv, Ukraine, postal code03037(pot1965@ukr.net)

ORCID: 0000-0003-3518-9280

ResearcherID: ABF-2675-2020

\section{Олексій ГОНЧАРЕНКО}

доктор історичних наук, професор кафедри теорії $i$ методики технологічної освіти і комп'ютерної графіки Університету Григорія Сковороди в Переяславі, вул. Сухомлинського 30, м. Переяслав, Київська обл., Україна, індекс 08401 (oleksijghoncharenko@gmail.com)

\section{Олександр ПОТИЛЬЧАК}

доктор історичних наук, професор, завідувач кафедри джерелознавства та спеціальних історичних дисииплін Національного педагогічного університету імені М. П. Драгоманова, вул. Освіти, 6, м. Киї, Украӥна, індекс 03037 (pot1965@ukr.net)

Bibliographic Description of the Article: Honcharenko, O. \& Potyl'chak, O. (2021). The Activity Issue of Local Authorities of the Reich Commissariat "Ukraine" (1941 - 1944) in Modern Ukrainian Histiriography. Skhidnoievropeiskyi istorychnyi visnyk [East European Historical Bulletin], 21, 149-161. doi: 10.24919/2519-058X.21.246911

\section{THE ACTIVITY ISSUE OF LOCAL AUTHORITIES OF THE REICH COMMISSARIAT "UKRAINE" (1941 - 1944) IN MODERN UKRAINIAN HISTORIOGRAPHY}

\footnotetext{
Abstract. The purpose of the article is a historiographical analysis of researches by domestic scholars on the activities of local authorities bodies of the Civil Administration of the Reich Commissariat "Ukraine" (hereinafter - the RCU) in the vertical of the Nazi occupation regime, clarifying the main directions of these studies, determining insufficiently studied issues and outlining promising areas for further research on this topic. The research methodology is based on the scientific principles of historicism, objectivity, continuity, scientificity and systematics. To study the historiographical context of the problem, the authors used the methods of historical comparative studies, source studies, structural
} 
and functional, retrospective analysis. The scientific novelty of the study consists in the systematic analysis of the main achievements and problematic issues of domestic historiography in the field of reconstruction of one of the little-known, in general, insufficiently studied and controversial pages of the past of Ukraine during the Nazi occupation of 1941 - 1944. The Conclusions. The issue of functioning peculiarities of local authorities bodies subordinated to the German civil administration of the RCU is analyzed quite actively in modern Ukrainian historiography. As a result of these researches the basic directions of activity and powers of regional, city and rural administrations in social and economic, cultural and educational, municipal and household spheres are found out. Objectively contributing to the implementation of the occupation policy tasks, these local authorities worked in parallel to meet the needs of local socium under the extreme conditions of the war. The regional aspects of local authorities functioning of the RCU seem to be studied sufficiently. The authors elucidated the organizational structure, official powers, clarified the relationship with the structures of the German military and civilian occupation authorities. Despite these positive tendencies, in the scientific narrative there is some confusion in the conceptual apparatus, especially in the segment of identifying these bodies as "self-governing", "Ukrainian" or "public". Some researchers exaggerate the participation of the OUN and nationally oriented Ukrainian intelligentsia in the creation and activity of local authorities bodies, in particular during the period when the occupied Ukrainian lands were under control of the German temporary military administration.

Key words: occupation regime, local authorities body, the Reich Commissariat "Ukraine", self-government, temporary military administration.

\title{
ПРОБЛЕМА ДІЯЛЬНОСТІ ОРГАНІВ МІСЦЕВОГО УПРАВЛІННЯ РАЙХСКОМІСАРІАТУ "УКРАЇНА" (1941 - 1944) У СУЧАСНІЙ УКРАЇНСЬКІЙ ІСТОРІОГРАФІЇ
}

\begin{abstract}
Анотація. Метою статті $\boldsymbol{\epsilon}$ історіографічний аналіз досліджень вітчизняних вчених з проблематики діяльності установ місиевого управління цивільної адміністраиії Райхскомісаріату “Украӥна" (далі - РКУ) у вертикалі органів нацистського окупаційного режсим, з'ясування головних напрямів ичих студій, виявлення недостатньо вивчених питань та окреслення перспективних напрямів подальших досліджень иієї тематики. Методологія дослідження трунтується на наукових принципах історизму, об'єктивності, наступності, науковості та системності. Для студіювання історіографічного контексту проблеми автори застосовують методи історичної компаративістики, джерелознавчого, структурнофункиіонального та ретроспективного аналізу. Наукова новизна дослідження полягає у системному аналізі основних здобутків $і$ проблемних питань вітчизняної історіографії у сфері реконструкиї̈ однієї з маловідомих, назагал недостатньо вивчених і контроверсійних сторінок минулого Украӥни доби нацистської окупаиії 1941 - 1944 рр. Висновки. Проблематика особливостей функиіонування органів місчевого управління, підпорядкованих німецькій цивільній адміністраиії РКУ, в сучасній украӥнській історіографії наразі розробляється доволі активно. У результаті ичих досліджень з'ясовано основні напрями діяльності та повноваження районних, міських і сільських управ у соиіально-економічній, культурно-освітній, комунальній та побутовій сферах. Об'єктивно сприяючи реалізаиії завдань окупачійної політики, ичі низові управлінські структури паралельно працювали й на забезпечення в екстремальних умовах війни потреб місиевого соиіуму. Достатньо вивченими виглядають регіональні аспекти функиіонування органів місцевого управління РКУ. Авторами встановлено їх організаиійну структуру, службові повноваження, з'ясовано взаємостосунки зі структурами німецької військової та ичивільної окупаційної влади. Попри изі позитивні тенденції, напращьований науковий наратив не позбавлений певної плутанини в понятійному апараті, особливо у сегменті ідентифікації ичих органів як “самоврядних”, “украӥнських” або ж “громадських”. Окремі дослідники гіперболізують участь осередків ОУН і національно орієнтованої украӥнської інтелігенції у створенні та діяльності інституцій місцевої влади, зокрема у період перебування окупованих українських земель під контролем тимчасової німецької військової адміністрації.
\end{abstract}

Ключові слова: окупаційний режсим, орган місчевого управління, Райхскомісаріат "Украйна", самоврядування, тимчасова військова адміністрачія. 
The Problem Statement. Documentary reconstruction of the objective events picture of the history of World War II and the Nazi occupation regime, established and maintained by the Nazis in Ukraine in 1941 - 1944, belongs to the range of leading objectives of modern domestic historiography. This process is facilitated by both democratization of a public life in the country and almost complete, in contrast to the Soviet period of time, openness of archival sources, in particular the so-called "occupation funds". Analyzing the occupation past in the aspect of power and society, modern researchers inevitably face the need to clarify the place and role of local authorities, which in the tradition of the post-Soviet historiography continue to be not quite justifiably called "subsidiary", in the system of the "new order" established on the territory and population of the Reich Commissariat "Ukraine". At the same time, the issue of the local authorities bodies functioning of the RCU are analyzed either superficially, within the framework of research on other aspects of the occupation period, or are singled out in a special subject of scientific research.

The Analysis of Recent Researches and Publications. Nowadays, domestic historical science has a fairly wide range of different in volume, depth and quality of scientific analysis of historical works, the subject of study which are certain aspects and features of rural, township and city administrations on the territory of the RCU, the functional component of these local authorities bodies is analyzed in the vertical of the Nazi "new order". At the same time, there is still a lack of deep historiographical analysis of the outlined range of issues. In general, these attempts were made by the authors of qualification research for Candidate of Sciences and Doctor of Sciences Degrees, and were published in separate sections of monographs by dissertators as approbation results of doctoral research. In professional scientific journals publications on this topic also belong to the post-graduates and were written by them in accordance with the procedure requirements for the qualifications research.

In the sphere of thematic special researches in which there were various, in particular regional aspects of local authorities bodies functioning of the RCU, there should be mentioned the monographs by Oleksiy Honcharenko (Honcharenko, 2011), Serhiy Stelnykovych (Stelnykovych, 2015; Stelnykovych, 2016), Yuri Levchenko (Levchenko, 2017), the dissertation researches of Lina Melnichuk (Melnichuk, 2013b), Bohdan Zek (Zek, 2016), Oleksandr Kostiuchok (Kostiuchok, 2012), Yuri Levchenko (Levchenko, 2015), Oleksandr Tishyn (Tishyn, 2020). There are also special monographic studies by O. Honcharenko and Mykhailo Kunytsky, in which the establishment and work issues of local authorities bodies of the RCU are analyzed (Honcharenko, 2014; Kunytsky, 2014). Nevertheless, there is still a lack of separate historiographical studies of the outlined scientific achievements. One of these historiographical studies has been recently published by the co-author of this article (Honcharenko, 2020б). Other similar studies are mostly small publications by Tetiana Zabolotna, L. Melnichuk and A. Ivanenko, the authors of which analyze some works of researchers known to them (Zabolotna, 2010; Melnichuk, 2012; Ivanenko, 2019b). It should be also mentioned that with few exceptions (Honcharenko, 2010; Honcharenko, 2020a), in modern domestic historiography there are almost no works, the subject of which is the activities of village and regional administrations under the Nazi occupation.

The purpose of the article is a historiographical analysis of researches by domestic historians on the activities of local authorities bodies of the civil administration of the RCU in the vertical of the Nazi occupation regime, clarifying the main directions of these studies, identifying insufficiently studied issues and outlining perspective areas for further research on this topic. 
The Main Material Statement. Researches on the reconstruction of the functional activities of local authorities bodies of the RCU, carried out by modern researchers, are mostly concentrated in several problem-thematic niches. There are the following ones among them: determining the legal status of local authorities bodies; finding out their place in the hierarchical vertical of the German occupation authorities; studying the facts of direct participation of local authorities officials in providing the repressive measures of the Nazis (including the Holocaust); analyzing the social and legal status of administrations employees of different levels; finding out the reasons for the participation of local population in the work of these authorities bodies.

Analyzing the work of modern Ukrainian researchers in the thematic context outlined in the title of the article, it is impossible to ignore the scientific heritage of Mykhailo Vasyliovych Koval, a famous historian, a researcher of the Ukrainian history during World War II (1939 1945). He was one of the first titled and well-known researcher in the domestic historians world, who in the mid-1990s made the so-called radical departure from the Soviet historiographical tradition and outlined a number of scientific problems of the Ukrainian history during the Nazi occupation, which remain completely or partially unanalyzed even nowadays. Among other problems of the occupation past, which, according to M. Koval, needed to be reconsidered, the researcher named the work of local authorities bodies on the Nazi-occupied territories. Presenting the German strategic line in conquered Ukraine as purely colonial, the historian noted that without the participation of local authorities, the Nazis would not have been able to implement in practice certain tasks of the occupation policy so quickly (Koval, 1999). The conceptual nature of M. Koval's research did not allow the author to dwell on clarifying the structure or official competence of local authorities bodies in detail.

In the mid-1990s Pavlo Rekotov initiated the tradition of an interdisciplinary historical and legal analysis of administrative bodies establishment and activity of the Nazi occupation regime. The author's historical research is characterized by the application of the legal science methods. The scientist clearly identifies local authorities bodies both during the period when the territory of Ukraine was in the area of responsibility of the temporary military administration, and after their transfer to the RCU. Having determined the organizational structure of the city, district and village administrations established by military officials, the researcher claimed that the RCU administration maintained the same approaches in its organizational and administrative activities.

Despite the undeniably positive features of P. Rekotov's researches, they did not do without obviously erroneous approaches in analyzing the nature of the RCU local authorities. These are the characteristics of the RCU rural and urban administrations proposed by the scientist as "public administrations" and "self-government bodies" (Rekotov, 1997). Describing local authorities as "self- government bodies", the researcher began a false tradition of identifying such local authorities bodies. These local authorities bodies under the Nazi occupation regime were not and could not be self-governing and have at least some signs of independence in decision-making. It should be noted that such authorities as "public administrations" did not operate in the military occupation zone or in the RCU. A short period of "public administrations" operation during the first weeks of the German occupation, mainly in the western regions of Ukraine, did not form any experience, because these bodies were liquidated.

Clarifying the typical organizational structure of local authorities bodies, P. Rekotov did not take into account some independence of the German military and civilian administrators in this issue. This independence led to the approval of different officials in staff lists of village and city administrations, to constant transformations, to the search of optimal management models, and etc. 
By analogy with P. Rekotov, Ivan Terliuk characterizes a typical structure of local authorities bodies. As a result, for some reason, the control of police departments activity was included into the list of official powers of local authorities bodies (Terliuk, 2009). The researchers did not take into consideration the fact that purely nominal inclusion of police departments into the staff lists of local authorities bodies did not mean the transfer of power to local authorities to control the activity of police departments. Moreover, the German administration sought to limit the powers of local authorities as much as possible, to turn them into an appendage necessary for the implementation of the main tasks of the occupation policy.

Oleksandr Lysenko, one of the leading researchers of the occupation period, does not consider the local authorities bodies established by the German authorities to be selfgoverning either. On the contrary, he argues that these local bodies, by their nature and official competence, were much closer to the subsidiary authorities than to the self-governing ones (Lysenko, 2009). Similar conceptual conclusions were developed by the historian in other, later publications (Honcharenko, 2010), as well as in a joint generalizing monograph by O. Honcharenko and M. Kunytsky (Honcharenko, 2014).

L. Melnichuk's dissertation is the only special research which deals with the study of the activity of local authorities bodies of the RCU. The author of this dissertation quite reasonably, on the basis of the analysis of various layers of archival sources, singles out the main directions of local authorities activity, proves their complete dependence on the German administration of the Reich Commissariat. L. Melnichuk states that the reason for the emergence of a certain degree of autonomy in the activity of city and district authorities was the administrative procedures introduced by regional and local leaders of the German authorities of the RCU. However, any act of disobedience or independence was punished by the German authorities severely and without any hesitation (Melnichuk, 2014).

The participation of local authorities in the economic and tax spheres was reconstructed in the works of Oleksandr Potylchak (Potylchak, 1999), Ihor Vietrov (Vietrov, 1999), Natalia Handrabura (Handrabura, 2017), Natalia Hlushenok (Hlushenok, 2005), Oleksandr Perekhrest (Perekhrest, 2011), M. Kunytsky (Kunytsky, 2019a, 2019b). This direction of local authorities activity is interpreted by the researchers as the one that corresponds to the general, strategic line of the German administration regarding the organization of an overall and openly predatory exploitation of all available resources of Ukraine to provide Germany and the Wehrmacht with food and raw materials. It is obvious that without a proper activity of local authorities bodies, the German occupation administration would not have been able to implement strategic and vital tasks under conditions of a total war.

The socio-cultural sphere in the local authorities activities during the occupation period was also the subject of research by modern domestic historians. These aspects of local authorities activities were studied by Inna Honcharenko (Honcharenko, 2012), O. Honcharenko (Honcharenko, 2014), Volodymyr Hinda (Hinda, 2007), O. Potylchak (Potylchak, 2006), Iryna Spudka (Spudka, 2013), Bohdan Kytsak (Kytsak, 2018). These authors review and analyze the activities of local authorities bodies in the field of resumption of general and vocational education. Historians interpret such steps of the occupation authorities as forced and caused by an acute shortage of qualified personnel in almost all sectors of economy and utilities. Domestic researchers focus on the provision of certain forms of social assistance to the local population, the organization of a medical care by the local authorities bodies.

A characteristic feature of a current state of researches on the activities of local authorities bodies of the occupation period is an active elaboration of regional thematic niches of the 
outlined issue. Therefore, the objective of such researches is to single out and analyze certain territorial specifics, which was found out in the activity of local authorities bodies. For example, S. Stelnykovych states that local authorities bodies established by the occupation administration of "Zhytomyr" General District were essentially subsidiary formations. The researcher emphasizes that some of these local authorities bodies were established by members of local branches of both factions of the OUN, "Polissia Sich", as well as individual representatives of the Ukrainian national intelligentsia. The specificity of this region was functioning of the Belarusian subsidiary administration at the beginning of the occupation. However, with the establishment of the RCU, the German occupation administration began a systematic elimination of the influence of nationalists on local authorities bodies, and previously controlled by nationalists various levels of authorities came under a total control of the German administration (Stelnykovych, 2016).

Regional features of local authorities bodies activities in different administrative districts of the RCU were analyzed by Valentyna Vlasenko (2013), Serhiy Ivanov (Ivanov, 2017), Volodymyr Udovyk (Udovyk, 2005), Bohdan Zek (Zek, 2016), T. Zabolotna (Zabolotna, 2010), O. Kostiuchok (Kostiuchok, 2012), Volodymyr Orliansky and Oleksandr Tedeiev (Orliansky \& Tedeiev, 2010), Yuriy Oliynyk and Oleksandr Zavalniuk (Oliynyk \& Zavalniuk, 2012). Clearly defined territorial issues of their studies relate to the analysis of the main areas of activity of local authorities, mostly in the socio-economic, cultural, educational and household spheres. It is also important that in their works the above mentioned authors trace the transformations and changes, which took place in the activity of local authorities bodies, especially after their transition under control of the civil administration of the RCU. However, there were recurrences of erroneous opinions of the 1990s concerning the nature of local authorities bodies activities during the occupation period as "self-governing".

Valentyna Shaikan analyzes the issue of the local authorities activity in the context of collaborationism manifestations on the occupied territory of Ukraine. The researcher elucidates different activity areas of local authorities, determines their structure, analyzes the activities of individual units, in particular, legal departments; in the context of collaborationism phenomenon she characterizes the activity of individual executives and ordinary employees (Shaikan, 2005). A. Ivanenko analyzes such a specific area of activity of local authorities as the establishment of a regulatory framework for the application of occupation criminal and civil law and justice (Ivanenko, 2019b).

Peculiarities of personnel formation of local authorities bodies on the territory of the RCU were studied by M. Kunytsky. According to the historian, the social and legal status of administrations employees of different levels was different from the rest of the civilian population and was determined, primarily, by the professional powers. Endowed with considerable rights, employees of district, city and village administrations had a privileged position. Their place between the German authorities and the local population was conditioned by the fact that the Nazis set them specific tasks, without a particular resorting to the means and methods of their implementation. The historian is convinced that the heads of administrations, although they could, within the limits of the issued normative prescriptions, at their own discretion determine the directions of realization of the tasks set by the occupiers, however, this fact did not mean their independence from the German administration (Kunytsky, 2014).

M. Koval also made some significant remarks concerning the staff of local authorities. The researcher argued that representatives of various social groups of the population of Ukraine went to work for the occupation authorities bodies. The researcher considered such 
behavior of people to be one of the consequences of the Bolshevik policy during the period of the 1920s and the 1930s (Koval, 1999).

Ihor Shakhraichuk, a researcher of Dnipropetrovsk city administration during the years of occupation, emphasized that in the activity of this administrative body took part mainly those citizens, who were oppressed by the Soviet authorities during the pre-war period, such as the former dispossessed, as well as representatives of the Bandera underground. In addition, the researcher pays tribute to the city administration in providing all possible social assistance to the poorest strata of the city population (Shakhraichuk, 2020). Another researcher of the history of Dnipropetrovsk during the Nazi occupation, Vladyslav Borysov, studies the issue of local intelligentsia participation in the activity of Dnipropetrovsk city administration. According to the author, despite solving the tasks on social assistance to the local population and the work to preserve the municipal infrastructure of the city, the practical activities of city administration officials were subordinated to the political, ideological and economic needs of the German authorities in general (Borysov, 2020).

One of the popular genres of researches on the occupation past is historical biographic studies. The subject of such researches is the details of the life and work of individual heads of local authorities. The authors: Ihor Verba (Verba, 1999), Vitaliy Hedz (Hedz, 2014), Oleksandr Kucheruk (Kucheruk, 2007), researching the personal stories of such people, not only dwell on the characteristics of these mostly extraordinary personalities, but also try to find out for what reasons and life circumstances these people agreed to work in the occupation apparatus of power. Characteristic features of the majority of these researches are avoiding any labelling of "traitors", who went to the service of the occupiers, and the depiction of the professional activities of these people in a much broader context of events. In particular, it concerns the activities of local authorities heads aimed at helping the local population to survive under the extreme conditions of the war.

The degree and nature of the participation of representatives of the local authorities bodies in providing repressive and punitive measures is an extremely difficult and contradictory issue, which researchers of the occupation period try to find out. It is obvious that local authorities did not have punitive functions in their list of powers. However, by their daily activities they formed the very system of occupation administration. Following the regulatory framework of the German authorities, local authorities ensured punitive actions, including those directed against the Jewish population of Ukraine. These aspects of local authorities activities are emphasized by O. Honcharenko (Honcharenko, 2010) and M. Kunytsky (Kunytsky, 2014).

A clear feature of the modern historiographical process in the context of research on the Nazi occupation regime in Ukraine is the formation of a national school of the Holocaust researchers. Some of its researchers consider, among other issues, the problems of local authorities bodies involvement in providing measures for the Nazi repression against the Jews. The limited scope of this publication does not allow us to do a detailed analysis of the entire layer of such studies. Therefore, we dwell on historiographical researches on this issue. In particular, the insufficient study of the issue of local authorities bodies participation in the Holocaust is emphasized by O. Honcharenko (Honcharenko, 2017) and Maryna Strilchuk (Strilchuk, 2018) in their publications. Some facts of the participation of local authorities bodies in the Holocaust were covered on the pages of the monograph by M. Kunytsky (Kunytsky, 2014), in the publications by Faina Vynokurova (Vynokurova, 2009) and Ihor Shchupak (Shchupak, 2012).

The participation of Dnipropetrovsk city administration in the registration of the local Jewish population is analyzed, in particular in a collective monograph edited by I. Shchupak. 
The authors of the monograph convince us that the local authorities did not organize the Holocaust in Dnipropetrovsk. Nevertheless, the local authorities, following the German regulations, carried out measures for the operational registration of the city Jewish population, distributed and used confiscated property for their own purposes. It is important that noncompliance with the orders of the city administration threatened the heads and owners of houses with repressions "according to the laws of wartime". The same can be said about discriminatory decisions of local authorities concerning food supply of the Jewish population of the city, who was deprived of food totally (Shchupak, 2017).

Roman Mykhalchuk analyzes organization and carrying out of passport-registration actions by local authorities of Rivne region. According to the text of his publication, the heads of local authorities took the appropriate measures not on their own initiative, but only on the basis of the mandatory German directives (Mykhalchuk, 2011). This author also did the research on the economic aspects of the Holocaust in the region. R. Mykhalchuk proves the fact of participation of local authorities of Rivne region in the robbery of real and movable property, which belonged to the Jews, in particular after the mass murders of the latter. All property of the Jewish population was registered by local authorities bodies, and a large part of it was recorded on the balance sheets of these authorities bodies after the murder of people (Mykhalchuk, 2013). R. Mykhalchuk drew the conclusion that the local authorities of Rivne region took part in the direct economic exploitation of these collective victims of the occupation regime (Mykhalchuk, 2015). The same economic aspects of the Holocaust, in particular the participation of local authorities employees, but on the example of Kyiv region, were analyzed by O. Honcharenko (Honcharenko, 2006).

The Conclusion. Nowadays, the peculiarities issues of functioning of local authorities bodies subordinated to the German civil administration of the RCU is analyzed quite actively in modern Ukrainian historiography. As a result of these researches the basic directions of activity and powers of regional, city and village administrations were found out in socio-economic, cultural and educational, municipal and household spheres. Objectively contributing to the tasks implementation of the occupation policy, these local authorities bodies worked in parallel to meet the needs of local socium under extreme conditions of the war.

The regional aspects of the local authorities bodies functioning of the RCU are studied sufficiently. The authors elucidated the organizational structure, official powers, clarified the relationship with the structures of the German military and civilian occupation authorities. Despite these positive tendencies, in this scientific narrative there is some confusion in the conceptual apparatus, especially in the segment of identification of these bodies as "selfgoverning", "Ukrainian" or "public".

Some researchers exaggerate the participation of the OUN and nationally oriented Ukrainian intelligentsia in the establishment and activity of local authorities bodies, in particular during the period when the occupied Ukrainian lands were under the control of the temporary German military administration.

The reasons for the participation of representatives of the Ukrainian civilian population in the work of local authorities bodies are largely explained by the consequences of the pre-war Soviet reality, or by the desire of people to survive on their own and save the lives of their loved ones under the extreme conditions of the war and occupation.

The participation of local authorities bodies of various levels in providing measures for the Holocaust remains a relatively insufficiently studied area of local authorities activity. Researchers, who work in this problem-based niche, mostly consider the participation of 
local authorities bodies in passport and registration activities and in organized property looting of the Jewish population.

Acknowledgement. The authors are sincerely grateful to all members of the editorial board for the advice provided during the preparation of the article for publishing.

Funding. The authors did not receive any financial support for doing the research and its publishing. publication.

\section{BIBLIOGRAPHY}

Borisov, V. \& Levin, O. (2020). Uchast intelihentsii u roboti orhaniv mistsevoho samovriaduvannia m. Dnipropetrovska u 1941 - 1943 rr. [Intelligentsia's Participation in the Work of Dnipropetrovsk District Government in the 1941 - 1943] Problemy politychnoi istorii Ukrainy - Problems of political history of Ukraine, 15, 131-160. doi: 10.33287/1193 [in Ukrainian]

Verba, I. (1999). Oleksandr Ohloblyn: Zhyttia i pratsia v Ukraini (Do 100-richchia z dnia narodzhennia) [Oleksandr Ohloblyn: Life and Labor in Ukraine (On the 100th anniversary of his birth)]. Kyiv: NAN Ukrainy. In-t ukr. arkheohrafii ta dzhereloznavstva im. M. S. Hrushevskoho, 384 p. [in Ukrainian]

Vetrov, I. G. (1999). Ekonomichna ekspansiia "tretoho reikhu” ta promyslovist Ukrainy v roky Druhoi svitovoi viiny [Economic Expansion of the "Third Reich" and the industry of Ukraine World War II] (Candidate's thesis). Kyiv, 243 p. [in Ukrainian]

Vynokurova, F. (2009). Evrey Vynnitsy v peryod natsystskoi okkupatsyy $1941-1944 \mathrm{hh}$. [The Jews of Vinnytsia during the Nazi Occupation of 1941 - 1944]. Abstracts of Papers 2009: Yevrei v Ukraini: istoriia ta suchasnist (pp. 401-414). Zhytomyr. [in Russian]

Vlasenko, V.V. (2013). Stvorennia ta diialnist orhaniv mistsevoho upravlinnia v heneralnomu okruzi "Zhytomyr" u roky nimetskoi okupatsii (1941 - 1944 rr.) [Creation and Activity of Local Autorities in the General District "Zhytomyr" during the Years of the German Occupation (1941 1944)] (Candidate's thesis). Kyiv, 208 p. [in Ukrainian]

Vradiy E. A., Rybalka V. G., Strilchuk M. V., Shatalov D. V., Shchupak I. Ya. (Comps.). (2017). Holokost u Dnipropetrovsku [The Holocaust in Dnipropetrovsk]. Dnipro: Ukrainskyi instytut vyvchennia Holokostu "Tkuma", LIRA, 256 p. [in Ukrainian]

Handrabura, N. (2017). Selo heneralnoi okruhy "Dnipropetrovsk" (1941-1944 rr.): vyzysk, vysnazhennia ta naslidky [Villages of Dnipropetrovsk General District (1941-1944): acquisitiveness, depletion and consequences] (Candidate's thesis). Mykolayiv, 251 p. [in Ukrainian]

Hedz, V. (2014). Diialnist O.Ohloblyna v Kyievi pid chas natsystskoho panuvannia [Activity of O. Ohloblyn in Kyiv during the Nazi Occupation]. Viiskovo-istorychnyi merydian-Military-historical meridian, 4, 49-58. [in Ukrainian]

Ginda, V. (2007). Osvita v roky nimetskoi okupatsii u heneralnomu okruzi "Zhytomyr" 1941 $1944 r r$. [Education during the Period of the German Occupation in the General District "Zhytomyr" in 1941 - 1944] (Candidate's thesis). Cherkasy, 243 p. [in Ukrainian]

Hlushenok, N. M. (2005). Ahrarna polityka Nimechchyny v reikhskomisariati "Ukraina" 1941 - 1944 rr. [Agrarian Policy of Germany in the Reich Commissariat "Ukraine"]. (Extended abstract of Candidate's thesis). Kyiv, 22 p. [in Ukrainian]

Honcharenko, I. V. (2012). Profesiina osvita na terenakh Raikhskomisariatu "Ukraina" (1941 1944 rr.) [Professional Education on the Territory of the Reich Commissariat "Ukraine" (1941 - 1944)]. (Candidate's thesis). Pereiaslav-Khmelnytskyi, 220 p. [in Ukrainian]

Honcharenko, O. M. (2017). Holokost na terenakh Raikhskomisariatu "Ukraina" u vitchyznianomu istoriohrafichnomu dyskursi (1941 - 2016 rr.). [Holocaust on the Territory of the Reich Commissariat "Ukraine" in the National Historiographical Discourse (1941 - 2016). Dnipro: Ukrainskyi instytut vyvchennia Holokostu "Tkuma", 258 p. [in Ukrainian]

Honcharenko, O. M., Honcharenko, I. V. \& Kunytskyi, M. P. (2014). Natsystska okupatsiina polityka u sferi osvity na terenakh Raikhskomisariatu "Ukraina" [The Nazi Occupation Policy in the Field of Education on the Territory of the Reich Commissariat "Ukraine"]. Kyiv: Profi, 232 p. [in Ukrainian] 
Honcharenko, O. M., Kunytskyi, M. P. \& Lysenko, O. Ye. (2014). Systema orhaniv mistsevoho upravlinnia na terytorii raikhskomisariatu "Ukraina" ta "viiskovoi zony". 1941 - 1944 rr. [The System of Local Government Bodies on the Territory of the Reich Commissariat "Ukraine" and "military zone”. 1941 -1944 rr.]. Kyiv: NAN Ukrainy. Instytut istorii Ukrainy, 151 p. [in Ukrainian]

Honcharenko, O., Lysenko, O. \& Pershyna, T. (2010). Systema upravlinnia okupovanymy terytoriiamy Ukrainy [Administration System of the Occupied Ukrainian Territory]. In V. A. Smolii (Ed.), Ukraina v Druhii svitovii viini: pohliad z XXI stolittia (Vol. 1, pp. 321-367). Kyiv: Naukova dumka. [in Ukrainian]

Honcharenko, O. (2006). Pozbavlennia yevreiskoho naselennia vlasnosti v period natsystskoi okupatsii Kyivshchyny [Deprivation of Property of the Jewish Population during the Nazi Occupation of Kyiv Region]. Chasopys ukrainskoi istorii - The Journal of Ukrainian History, 5, 116-121. [in Ukrainian]

Honcharenko, O.(2020a). Problema kolaboratsionizmu na terenakh Raikhskomisariatu "Ukraina" ta viiskovoi zony okupatsii $v$ suchasnii vitchyznianii istoriohrafii: instytutsiine vyznachennia zmistu ta form spivpratsi, osnovni tendentsii istorychnykh rekonstruktsii (1991 - $2019 \mathrm{rr}$.) [The Problem of Collaborationism on the Territory of the Reich Commissariat "Ukraine" and the Military Zone of Occupation in Modern Domestic Historiography: institutional definition of the content and forms of cooperation, the main trends of historical reconstructions (1991 - 2019)]. Kyiv: NAN Ukrainy, Instytut istorii Ukrainy, 188 p. [in Ukrainian]

Honcharenko, O. (2020b). Mistse oblasnykh uprav u systemi hitlerivskoho okupatsiinoho aparatu vlady: protses stvorennia, sluzhbovi kompetentsii, kharakterystyky kerivnykiv $(1941-1942)$ [The Place of Regional Administrations in the System of Hitler's Occupation Apparatus of Power: the process of creation, service competencies, characteristics of leaders (1941 - 1942)]. Naukovi zapysky Vinnytskoho derzhavnoho pedahohichnoho universytetu imeni Mykhaila Kotsiubynskoho. Seriia: Istoriia-Scientific notes of Vinnytsia State Pedagogical University named after Mykhailo Kotsyubynsky. Series: History, 31, 53-62. doi: 10.31652/2411-2143-2019-31. [in Ukranian]

Honcharenko, O. (2010). Silski upravy v systemi okupatsiinoho aparatu vlady raikhskomisariatu "Ukraina": orhanizatsiina struktura, kompetentsiia ta dosvid funktsionuvannia (1941 - 1944 rr.) [Village Administrations in the System of the Occupation Apparatus of Power of the Reich Commissariat "Ukraine": organizational structure, competence and experience of functioning (1941 - 1944)]. Ukrainskyi selianyn - Ukrainian peasant, 12, 243-247. [in Ukrainian]

Honcharenko, O. M. (2011). Funktsionuvannia okupatsiinoi administratsii Raikhskomisariatu "Ukraina": upravlinsko-rozporiadchi ta orhanizatsiino-pravovi aspekty (1941 - 1944 rr.) [Functioning of the Occupational Administration of the Reich Commissariat "Ukraine": administrative, organizational and legal aspects (1941 - 1944)]. Kyiv: NPU imeni M.P.Drahomanova, 600 p. [in Ukrainian]

Zabolotna, T. (2010). Intelihentsiia $\mathrm{v}$ mistsevykh orhanakh vlady $\mathrm{v}$ roky natsystskoi okupatsii: istoriohrafiia problemy [Intellectuals in Local Authorities during the Nazi Occupation: Historiography of the Problem]. Storinky voiennoi istorii Ukrainy - Pages of the military history of Ukraine, 13, 40-53. [in Ukrainian]

Zabolotna, T. (2008). Povsiakdenne zhyttia naselennia Kyieva v roky natsystskoi okupatsii $1941-1943$ rr. [Everyday life of the Population of Kyiv during the Years of the Nazi Occupation of 1941 - 1943]. (Extended abstract of Candidate's thesis). Kyiv, 20 pp. [in Ukrainian]

Zek, B. M. (2016). Lutsk u roky natsystskoi okupatsii (1941 - 1944 rr.) [Lutsk during the Period of the Nazi Occupation (1941 - 1944] (Candidate's thesis). Lutsk, 239 p. [in Ukrainian]

Ivanenko, A. (2018). Sproby stvorennia tsyvilno-protsesualnykh norm v Ukraini u period natsystskoi okupatsii (osin 1941 r.) [Attemps to Create Civil and Procedural Norms in Ukraine during the Period of the Nazi Occupation (autumn of 1941)]. Pereiaslavskyi litopys-Pereiaslav chronicle, 14, 28-35. doi: 10.5281/zenodo.2267812 [in Ukrainian]

Ivanenko, A. (2019a). Ukrainske suspilstvo v leshchatakh natsystskoho "Novoho poriadku": ohliad suchasnykh vitchyznianykh dysertatsiinykh doslidzhen [Ukrainian Society in the Grip of the Nazi "New Order": an Overview of Modern Domestic Dissertation Research]. Naukovi zapysky istorychnoho fakultetu Zaporizkoho natsionalnoho universytetu - Scholarly Works of the of History, Zaporizhzhya National University, XXXXXII, 30-37. doi: 10.26661/swfh-2019-52-034 [in Ukrainian] 
Ivanenko, A. (2019b). Osoblyvosti stvorennia tsyvilno-protsesualnoho prava periodu natsystskoi okupatsii Ukrainy (1941 - 1944 rr.) [Peculiarities in the Creation of Civil Procedures Law during the Period of the Nazi Occupation of Ukraine (1941 - 1944)]. Skhidnoievropeiskyi istorychnyi visnyk East European Historical Bulletin, 11, 159-168. doi: 10.24919/2519-058x.11.170710 [in Ukrainian]

Ivanov, S. S. (2017). Stanovyshche naselennia Volyni v period nimetskoi okupatsii (1941 - 1944 rr.) [The Position of Volyn's Population during the Nazi German Occupation (1941 - 1944)]. (Candidate's thesis). Ostroh, 242 p. [in Ukrainian]

Kytsak, B. V. (2018). Medychne zabezpechennia naselennia u Raikhskomisariati "Ukraina" $v 1941-1944$ rr. [Medical Provision of the Population in the Reich Commissariat "Ukraine" during the Years of 1941 - 1944] (Candidate's thesis). Zhytomyr, 242 p. [in Ukrainian]

Koval, M. V. (1999). Ukraina v Druhii svitovii i Velykii Vitchyznianii viinakh (1939-1945 pp.). Ukraine in World War II and Great Patriotic War (1939 - 1945). Kyiv: Alternatives, 336 p. [in Ukrainian]

Kostiuchok, O. V. (2012). Stvorennia Kyivskoi miskoi upravy ta yii diialnist u sotsialnii $i$ ekonomichnii sferakh (veresen 1941 r. - liutyi 1942 rr.) [Establishment of Kyiv City Council and its Activities in the Social and Economic Field (September of 1941 - February of 1942)]. (Candidate's thesis). Kyiv, 229 p. [in Ukrainian]

Kunytsky, M. P. (2014). Sotsialno-pravovyi status mistsevoho naselennia Raikhskomisariatu "Ukraina" (1941 - 1944 rr.) [Socio-legal Status of the Local Population of the Reich Commissariat "Ukraine" (1941 - 1944)]. Kyiv: Profi, 564 p. [in Ukrainian]

Kunytsky, M. P. (2019a). Normatyvne zabezpechennia zboru podatkiv ta podatkovykh platezhiv na koryst nimetskykh sluzhb ta ustanov Raikhskomisariatu "Ukraina" (1941 - 1944 rr.) [Normative Provision of Collection of Taxes and Tax Payments in Favor of the German Services and Institutions of the Reich Commissariat "Ukraine" (1941 - 1944)]. Hileia: naukovyi zhurnal - Hileya: Scientific Bulletin, 151, 78-82. [in Ukrainian]

Kunytsky, M. P. (2019b). Naturalni podatky v systemi ekonomichnoi ekspluatatsii mistsevoho naselennia na terenakh Raikhskomisariatu "Ukraina" (1941-1944 rr.) [Natural Taxes in the Economic Exploitation of the Population on the Territory of the Reichs Commissariat "Ukraine" (1941 - 1944)]. Hileia: naukovyi zhurnal - Hileya: Scientific Bulletin, 141, 84-89. [in Ukrainian]

Kucheruk, O. (2007). Volodymyr Bahazii - miskyi holova Kyieva u 1941 - 1942 rr. [Volodymyr Bahaziy - the Mayor of Kyiv from 1941 to 1942]. Abstracts of Papers '2007: Druha svitova viina $i$ dolia narodiv Ukrainy (pp. 39-41). Kyiv. [in Ukrainian]

Levchenko, Y. I. (2015). Osoblyvosti realizatsii polityky okupatsiinoi vlady v administratyvnoterytorialnykh odynytsiakh Ukrainy 1941 - 1944 rr. [Particularities of Implementation of Occupational Authorities Policy in Administrative and Territorial Entities of Ukraine in 1941 - 1944]. (Candidate's thesis). Kyiv, 319 p. [in Ukrainian]

Levchenko, Yu. I. (2017). Osoblyvosti realizatsii polityky okupatsiinoi vlady v administratyvnoterytorialnykh odynytsiakh Ukrainy 1941 - 1944 rr. [Particularities of Implementation of Occupational Authorities Policy in Administrative and Territorial Entities of Ukraine in 1941 - 1944]. Kyiv: Vyd-vo NPU imeni M. P. Drahomanova, 409 p. [in Ukrainian]

Lysenko, O. Ye. (2009). Systema upravlinnia okupovanymy terytoriiamy Ukrainy [Management System on the Occupied Territories of Ukraine]. In V. A. Smolii (Ed.), Istoriia derzhavnoi sluzhby $v$ Ukraini (Vol. 5, pp. 393-414). Kyiv: Nika-Tsentr. [in Ukrainian]

Tishyn, O. V. (2020). Nimetske okupatsiine tsyvilne upravlinnia na Pivdni Ukrainy (1941 - 1943 rr.): administratyvno-politychnyi ta sotsialno-ekonomichnyi aspekty [The German Occupation Civilian Administration in the South of Ukraine (1941 - 1943)]. (Candidate's thesis). Zaporizhzhia, 277 p. [in Ukrainian]

Melnichuk, L. (2012). Problemy funktsionuvannia orhaniv mistsevoho upravlinnia Raikhskomisariatu "Ukraina" u suchasnii vitchyznianii istoriohrafii. [Problems of Operation of the Local Reich Commissariat "Ukraine" in Modern National Historiography]. Naukovi zapysky z ukrainskoi istorii - Scientific notes on ukrainian history, 32, 271-276. [in Ukrainian]

Melnichuk, L. V. (2014). Funktsionuvannia orhaniv mistsevoho upravlinnia okupatsiinoi administratsii Raikhskomisariatu "Ukraina" (1941 - 1944 rr.) [Functioning the Local Government 
of Occupation Administration the Reich Commissariat "Ukraine" (1941 - 1944)] (Candidate's thesis). Pereiaslav-Khmelnytskyi, 271 p. [in Ukrainian]

Mykhalchuk, R. (2011). Reiestratsiia ta identyfikatsiia yevreiv Rivnenshchyny yak pidhotovchyi etap u vyrishenni "ievreiskoho pytannia" [Registration and Identification of the Jews of Rivne region as a Preparatory Stage in Solving the "Jewish Issue"]. Aktualni problemy vitchyznianoi ta vsesvitnoi istorii - Current issues of national and world history, 22, 237-241. [in Ukrainian]

Mykhalchuk, R. (2013). Vlasnist yevreiv Rivnenshchyny pid chas natsystskoi okupatsii (1941 1944 rr.) [Property of Rivne Region Jews during the Nazi Occupation (1941 - 1944)]. Naukovi zapysky istorychnoho fakultetu Zaporizkoho natsionalnoho universytetu - Scholarly Works of the History, Zaporizhzhia National University, XXXVI, 169-173. [in Ukrainian]

Mykhalchuk, R. (2015). Trudova ekspluatatsiia zhertv Holokostu (na prykladi Rivnenshchyny) [Labor Exploitation of the Holocaust (on the example of Rivne region)]. Ivan Ohiienko i suchasna nauka ta osvita: naukovyi zbirnyk: seriia istorychna ta filolohichna - Ivan Ohienko and modern science and education: Scientific Journal: Historical and Philological Series, XI, 102-109. [in Ukrainian]

Oliinyk, Yu. V. \& Zavalniuk, O. M. (2012). Natsystskyi okupatsiinyi rezhym u heneralnii okruzi "Volyn - Podillia" (1941 - 1944 rr.) [The Nazi Occupation Regime in the General District "Volyn Podillya" (1941 - 1944)]. Khmelnytskyi: Polihrafist-2, 320 p. [in Ukrainian]

Orlianskyi, V.S. \& Tedeiev, O. S. (2010). Mistsevi orhany upravlinnia v period nimetskoi okupatsii na Zaporizhzhi (1941 - 1943 rr. [Local Authorities during the German Occupation of Zaporizhzhia (1941-1943)]. Kyiv: Tsentr navchalnoi literatury, 332 p. [in Ukrainian]

Perekhrest, O. H. (2011). Ukrainske selo v 1941 - 1945 rr.: ekonomichne ta sotsialne stanovyshche [Ukrainian Village in 1941 - 1945: economic and social situation]. Cherkasy: ChNU imeni B. Khmelnytskoho, 668 p. [In Ukranian]

Potylchak, O. V. (1999). Ekspluatatsiia trudovykh resursiv Ukrainy hitlerivskoiu Nimechchynoiu u roky okupatsii [Exploitation of Ukraine's Human Resources by Hitler's Germany during the Years of Occupation]. (Candidate's thesis). Kyiv, 205 p. [in Ukrainian]

Potylchak, O. V. (2006). The Nazi policy in the Field of Training Specialists with Secondary and Higher Special Education in Ukraine (1942 - 1944). Arkhivy okupatsii - Archives of Occupation. 1941 - 1944 (pp. 782-790). Kyiv: Vydavnychyi dim "Kyievo-Mohylianska akademiia”. [in Ukranian]

Rekotov, P. V. (1997) Orhany upravlinnia na okupovanii terytorii Ukrainy (1941 - 1944 rr.) [Governing Bodies on the Occupied Territory of Ukraine (1941 - 1944)]. Ukrains 'kyj istorychnyj zhurnal - Ukrainian Historical Journal, 3, 90-101. [in Ukrainian]

Spudka, I. (2007). Nimetska okupatsiina polityka u sotsiokulturnii sferi v reikhskomisariati "Ukraina" (1941 - 1944) [German Occupation Authority in Socio-cultural Field in the Reich Commissariat "Ukraine" (1941 - 1944)] (Candidate's thesis). Zaporizhzhia. 229 p. [in Ukrainian]

Spudka, I. (2013). Nimetska okupatsiina polityka u sotsiokulturnii sferi na terytorii Zaporizkoi oblasti [The Nazi Occupation Policy in Cultural Sphere on the Territory of Zaporizhzhia region]. Hileia: naukovyi zhurnal - Hileya: Scientific Bulletin, 75, 98-100. [in Ukrainian]

Stelnykovych, S. V. (2015). Zhytomyrsko-vinnytskyi rehion v umovakh natsystskoi okupatsii (1941 - 1944 rr.). [Zhytomyr-Vinnytsia Region under the Nazi Occupation (1941 - 1944)]. Zhytomyr: PP Yevenok O.O., 592 p. [in Ukrainian]

Stelnykovych, S. V. (2016). Natsystskyi okupatsiinyi rezhym na terytorii ZhytomyrskoVinnytskoho rehionu i mistseve naselennia: paraleli isnuvannia y borotby (1941 - 1944 rr.). [The Nazi Occupation Regime in Zhytomyr and Vinnytsia Region and the Local Population: Parallels in Daily Life and Struggle (1941 - 1944)] (Doctor's thesis). Kyiv, 522 p. [in Ukrainian]

Strilchuk, M. (2018). Holokost v Ukraini: istoriohrafichnyi aspekt [The Holocaust in Ukraine: historiographical aspect]. Universum istorii ta arkheolohii - The Universe of History and Archeology, 1-2, 128-136. DOI: 10.15421/2611815. [in Ukrainian]

Terliuk, I. Ya. (2009). Okupatsiinyi rezhym v Ukraini 1941 - 1944 rr. i problemy tvorennia ukrainskoi natsionalnoi derzhavnosti: istoriia derzhavy i prava [Occupation Regime in Ukraine in 1941 - 1944 and Problems of Creation of the Ukrainian National Statehood: history of the state and law]. Lviv: Kameniar, 126 p. [in Ukrainian] 
Udovyk, V. M. (2005). Nimetsko-fashystskyi okupatsiinyi rezhym (1941 - 1944 rr.) na terytorii heneralnoi oblasti "Kyiv" (Kyivska ta Poltavska oblasti) [The Nazi occupation regime (1941 1944) at the territory of the general region "Kyiv" (Kyiv and Poltava regions)]. (Candidate's thesis). Kyiv, 236 p. [in Ukrainian]

Shaikan, V. O. (2005). Kolaboratsionizm na terytorii Reikhskomisariatu "Ukraina" ta viiskovoi zony $v$ period Druhoi svitovoi viiny [Collaboration on the Territory of the Reich Commissariat "Ukraine" and the Military Zone during World War II]. Kryvyi Rih: Mineral, 564 p. [in Ukrainian]

Shakhraichuk, I. (2020). Orhanizatsiina dialnist Ukrainskoi dopomizhnoi upravy m. Dnipropetrovsk v period natsystskoi okupatsii 1941 - 1943 rr. (Za materialamy kryminalnoslidchykh sprav upravlinnia SBU u Dnipropetrovskii oblasti) [Organizational Activity of the Ukrainian Auxiliary Administration of Dnipropetrovsk during the Nazi occupation in 1941 - 1943 (According to the Materials of Criminal Investigation Cases of the SBU Department in Dnipropetrovsk Region)]. Problemy politychnoi istorii Ukrainy - Problems of political history of Ukraine, 15, 137-142. doi: $10.33287 / 11934$ [in Ukrainian]

Shchpak, I., (2012). Trahediia yevreiv Ukrainy [The Tragedy of the Jews of Ukraine]. In V. A. Smolii (Ed.), Natsionalne pytannia v Ukraini XX - pochatku XXI st.: istorychni narysy (pp. 402-424). Kyiv: Nika-Tsentr. [in Ukrainian]

The article was received Novemver 21, 2020. Article recommended for publishing 24/11/2021. 